\title{
KAJIAN PERUBAHAN STATUS JALAN JALAN LINGKAR LUAR GORONTALO
}

\author{
Tilaka Wasanta \\ Jurusan Teknik Sipil \\ Universitas Katolik Parahyangan \\ Jln. Ciumbuleuit No. 94 \\ Bandung 40141 \\ tilakaw@unpar.ac.id
}

\author{
Bertho Orbain Sowolino \\ Subdit Standar dan Pedoman \\ Direktorat Pembangunan Jalan \\ Direktorat Jenderal Bina Marga \\ Kementerian Pekerjaan Umum dan Perumahan Rakyat \\ Jln. Pattimura No. 20, Jakarta Selatan \\ berthoorbains@gmail.com
}

\author{
Zakaria Mujahid \\ Subdit Standar dan Pedoman \\ Direktorat Pembangunan Jalan \\ Direktorat Jenderal Bina Marga \\ Kementerian Pekerjaan Umum dan Perumahan Rakyat \\ Jln. Pattimura No. 20, Jakarta Selatan \\ Zakaria.mujahid@yahoo.co.id
}

\author{
Wimpy Santosa \\ Jurusan Teknik Sipil \\ Universitas Katolik Parahyangan \\ Jln. Ciumbuleuit No. 94 \\ Bandung 40141 \\ wimpy.santosa@gmail.com
}

\begin{abstract}
A road, as the most important infrastructure on land transportation, plays a huge role on the movement of passengers and freight. According to its status, road is classified into national road, province road, city road, district road, and village road. The status of a road significantly affects the process of financing, planning, construction, and maintenance of that road. Therefore, a comprehensive study is needed before the status of a road is determined or changed. This paper discusses several aspects that are needed to be considered before the status of a road is determined or changed, with a case study of Gorontalo Outer Ring Road. These aspects are centre-of-activity hierarchy, road geometry, and the traffic volume. After all those aspects were discussed, the recommended status of Gorontalo Outer Ring Road is concluded.
\end{abstract}

Keywords: rroad, land transportation, road status, centre-of-activity

\begin{abstract}
Abstrak
Jalan sebagai prasarana utama transportasi darat memegang peranan penting terhadap pergerakan barang maupun pergerakan orang. Menurut statusnya, jalan dikelompokkan menjadi jalan nasional, jalan provinsi, jalan kota, jalan kabupaten, dan jalan desa. Penetapan status suatu jalan berdampak besar pada kegiatan pembiayaan, perencanaan, pembangunan, dan pemeliharaan jalan tersebut. Oleh karena itu, diperlukan kajian yang mendalam sebelum suatu jalan ditetapkan atau diubah statusnya. Pada studi ini dikaji aspek-aspek yang perlu diperhatikan ketika suatu ruas jalan akan ditetapkan atau diubah statusnya, dengan studi kasus Jalan Lingkar Luar Gorontalo. Aspek-aspek yang dibahas pada penelitian ini adalah aspek hierarki pusat kegiatan, aspek geometri jalan, dan aspek lalu lintas. Setelah semua aspek tersebut dibahas, dapat disimpulkan status jalan yang sesuai untuk Jalan Lingkar Luar Gorontalo.
\end{abstract}

Kata-kata kunci: jalan, transportasi darat, status jalan, pusat kegiatan

\section{PENDAHULUAN}

Prasarana jalan memiliki pengaruh yang sangat besar terhadap pergerakan orang maupun pergerakan barang. Salah satu aspek yang perlu diperhatikan pada kegiatan penyelenggaraan prasarana jalan adalah penetapan status jalan. Penetapan status jalan sangat 
berkaitan dengan kegiatan pembiayaan, perencanaan, pembangunan, penanganan, dan pemeliharaan jalan (Purnomo dan Rahardjo, 2014). Selain itu, penetapan status jalan juga sangat memengaruhi pengembangan wilayah dan perencanaan sistem jaringan jalan di masa depan (Fachrie dan Rudiarto, 2016). Dengan melihat pentingnya penetapan status jalan, diperlukan studi yang tepat dalam menentukan atau mengubah status suatu ruas jalan.

Sebelum studi mengenai perubahan status jalan dapat dilakukan, hal pertama yang harus ditinjau adalah kondisi jaringan jalan eksisting. Jaringan jalan nasional di Provinsi Gorontalo tertuang dalam Keputusan Menteri PUPR Nomor 248/KPTS/M/2015. Daftar jaringan jalan nasional di Provinsi Gorontalo disajikan pada Tabel 1 dan peta jaringan jalan nasional tersebut dapat dilihat pada Gambar 1.

Tabel 1 Daftar Jaringan Jalan Nasional Provinsi Gorontalo

\begin{tabular}{|c|c|c|c|c|c|c|c|}
\hline No. & \multicolumn{3}{|c|}{ Nomor Ruas } & Nama Ruas & $\begin{array}{c}\text { Panjang Ruas } \\
(\mathrm{km})\end{array}$ & $\begin{array}{l}\text { JAP } \\
(\mathrm{km})\end{array}$ & $\begin{array}{c}\mathrm{JKP}-1 \\
(\mathrm{~km})\end{array}$ \\
\hline 1 & \multicolumn{3}{|l|}{001} & Atinggola (Bts. Prov. Sulut)-Kwandang & 40,41 & 40,41 & \\
\hline 2 & \multicolumn{3}{|l|}{002} & Kwandang-Malingkaputo & 11,99 & 11,99 & \\
\hline 3 & \multicolumn{3}{|l|}{003} & Malingkaputo-Tolango & 17,00 & & 17,00 \\
\hline 4 & \multicolumn{3}{|l|}{004} & Tolango-Bulontio & 56,05 & & 56,05 \\
\hline 5 & \multicolumn{3}{|l|}{005} & Bulontio-Tolinggula (Bts. Prov. Sulteng) & 55,50 & & 55,50 \\
\hline 6 & \multicolumn{3}{|l|}{006} & $\begin{array}{l}\text { Taludaa (Bts. Prov. Sulut)-Pel. } \\
\text { Gorontalo }\end{array}$ & \multicolumn{2}{|l|}{67,70} & 67,70 \\
\hline 7 & 006 & 11 & $\mathrm{~K}$ & Jln. Mayor Dullah (Gorontalo) & 7,36 & & 7,36 \\
\hline 8 & 006 & 12 & $\mathrm{~K}$ & Jln. Jalaludin Tantu (Gorontalo) & 0,71 & & 0,71 \\
\hline 9 & 006 & 13 & $\mathrm{~K}$ & Jln. A. Yani (Gorontalo) & 0,70 & & 0,70 \\
\hline 10 & \multicolumn{3}{|l|}{007} & Bts. Kota Gorontalo-Bts. Kota Limboto & 7,24 & 7,24 & \\
\hline 11 & 007 & 11 & $\mathrm{~K}$ & Jln. Basuki Rachmat (Gorontalo) & 0,57 & 0,57 & \\
\hline 12 & 007 & 12 & $\mathrm{~K}$ & Jln. Agus Salim (Gorontalo) & 4,67 & 4,67 & \\
\hline 13 & 007 & 13 & $\mathrm{~K}$ & Jln. Sudirman (Limboto) & 3,10 & 3,10 & \\
\hline 14 & \multicolumn{3}{|l|}{008} & Bts. Kota Limboto-Isimu & 6,20 & 6,20 & \\
\hline 15 & 008 & 11 & $\mathrm{~K}$ & Jln. A. Yani (Limboto) & 0,87 & 0,87 & \\
\hline 16 & 008 & 12 & $\mathrm{~K}$ & Jln. Raya Limboto (Limboto) & 7,87 & 7,87 & \\
\hline 17 & \multicolumn{3}{|l|}{009} & Isimu-Paguyaman & 41,72 & 41,72 & \\
\hline 18 & 009 & 11 & $\mathrm{~K}$ & Jln. Akses Ke Bandara Jalaluddin & 1,47 & 1,47 & \\
\hline 19 & \multicolumn{3}{|l|}{010} & Paguyaman-Tabulo & 63,08 & 63,08 & \\
\hline 20 & \multicolumn{3}{|l|}{011} & Tabulo-Marisa & 28,00 & 28,00 & \\
\hline 21 & \multicolumn{3}{|l|}{012} & Marisa-Lemito & 68,19 & 68,19 & \\
\hline 22 & \multicolumn{3}{|l|}{013} & Lemito-Molosipat (Bts. Prov. Sulteng) & 33,31 & 33,31 & \\
\hline 23 & \multicolumn{3}{|l|}{014} & Malingkapoto-Isimu & 19,13 & 19,13 & \\
\hline 24 & \multicolumn{3}{|l|}{015} & Kwandang-Pelabuhan Kwandang & 2,26 & & 2,26 \\
\hline 25 & \multicolumn{3}{|l|}{016} & $\begin{array}{l}\text { Sp. Pelabuhan Anggrek-Pelabuhan } \\
\text { Anggrek }\end{array}$ & 2,68 & & 2,68 \\
\hline 26 & \multicolumn{3}{|l|}{017} & Tolango-Paguyaman & 59,16 & & 59,16 \\
\hline 27 & \multicolumn{3}{|l|}{018} & Marisa-Desa Talu Diti & 40,00 & & 40,00 \\
\hline 28 & 018 & 2 & & Desa Bogo-Bogo-Tolinggula & 20,00 & & 20,00 \\
\hline 29 & \multicolumn{3}{|l|}{019} & Gorontalo-Biluhu Barat & 27,90 & & 27,90 \\
\hline 30 & 019 & 11 & $\mathrm{~K}$ & Jln. Kalengkongan (Gorontalo) & 1,77 & & 1,77 \\
\hline 31 & 019 & 12 & $\mathrm{~K}$ & Jln. Yos Sudarso (Gorontalo) & 2,40 & & 2,40 \\
\hline 32 & 019 & 13 & $\mathrm{~K}$ & Jln. Botuliyodu (Gorontalo) & 4,00 & & 4,00 \\
\hline 33 & 020 & & & Biluhu Barat-Bilato & 28,90 & & 28,90 \\
\hline 34 & 021 & & & Bilato-Tangkobu & 16,70 & & 16,70 \\
\hline & & & $10 c_{0}$ & Panjang Jalan Nasional & 748,61 & 337,82 & 410,79 \\
\hline
\end{tabular}




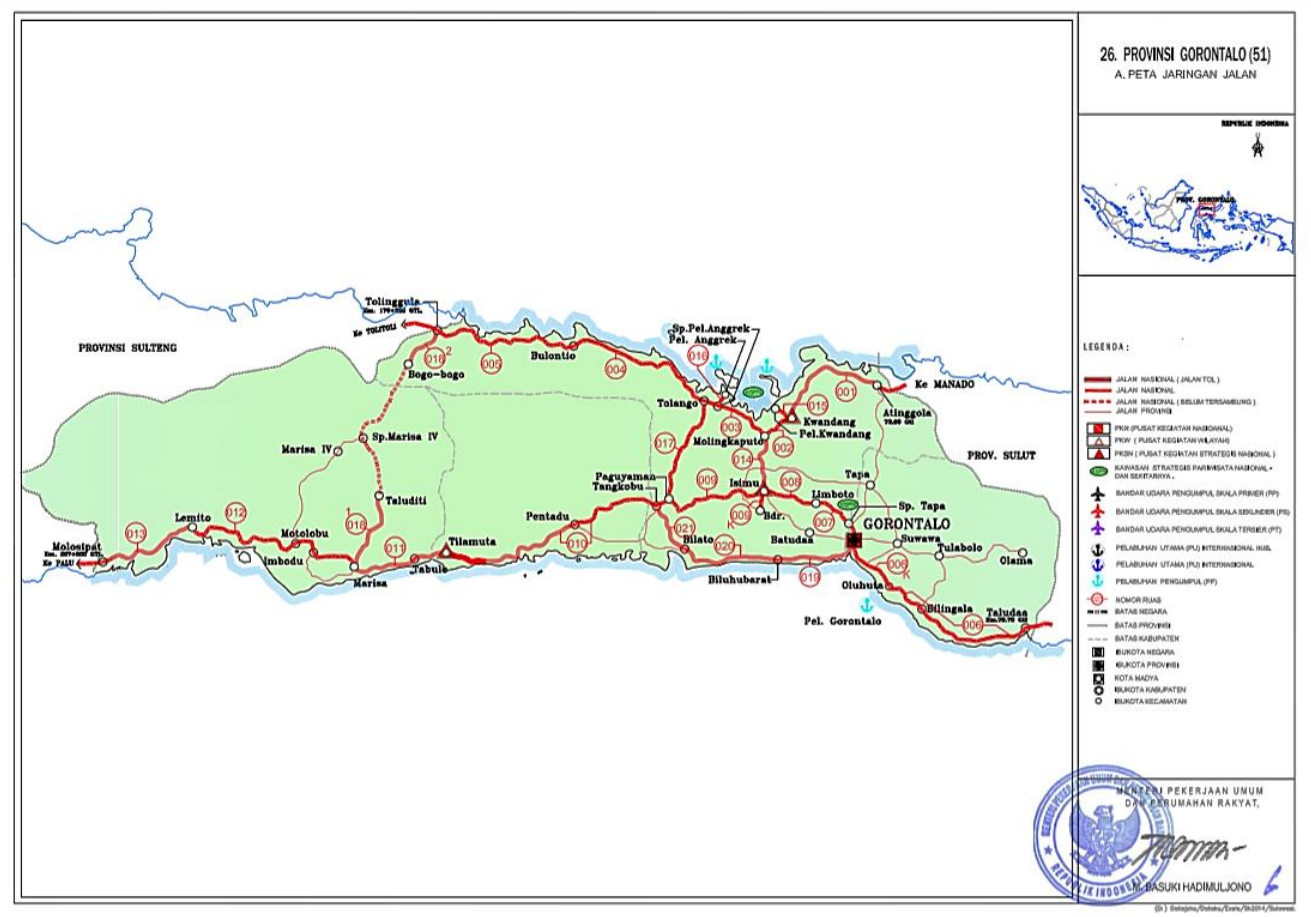

Sumber: Kementerian PUPR (2015a).

Gambar 1 Jaringan Jalan Nasional di Provinsi Gorontalo

Dalam rencana pengembangan jalan di Gorontalo terdapat rencana pembangunan jalan lingkar luar. Jalan Lingkar Luar Gorontalo, atau disebut Gorontalo Outer Ring Road (GORR), ini direncanakan dibangun untuk menghubungkan Bandara Djalaludin dengan Pelabuhan Ferry. Rencana Ruas Jalan Lingkar Luar Gorontalo disajikan pada Gambar 2.

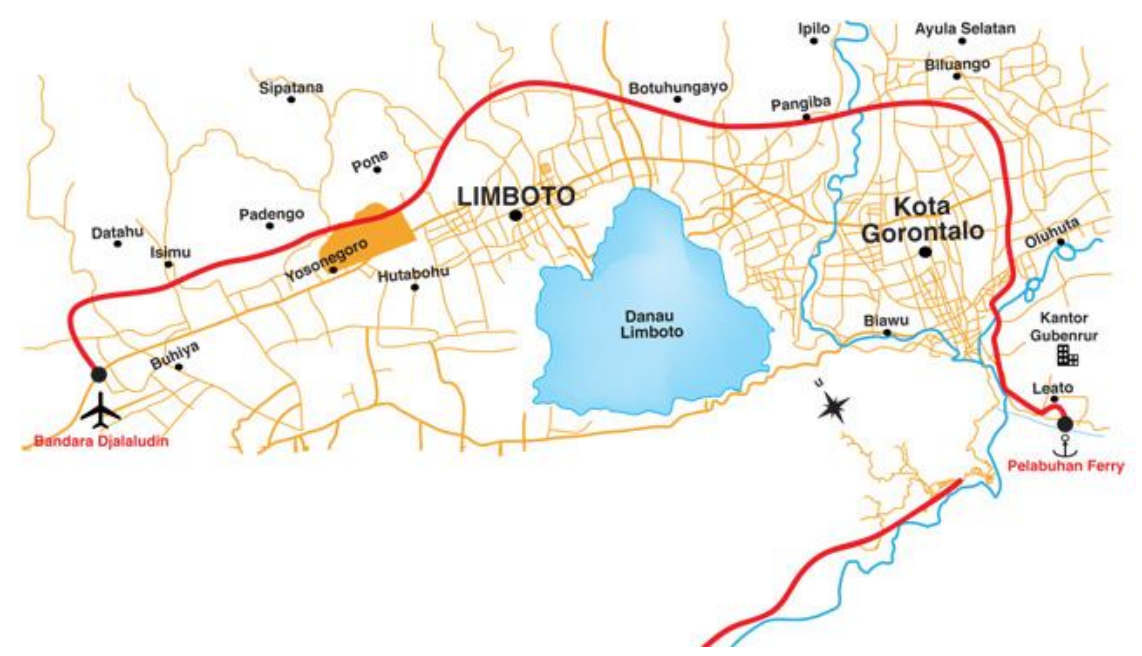

Gambar 2 Ruas Jalan Lingkar Luar Gorontalo

Saat ini sebagian ruas Jalan Lingkar Luar Gorontalo sudah terbangun, dengan satu segmen yang belum terbangun terletak di bagian timur dekat Kota Gorontalo. Karena jalan tersebut baru dibangun, status Jalan Lingkar Luar Gorontalo saat ini masih nonstatus. Penelitian ini membahas rencana penetapan status jalan untuk Jalan Lingkar Luar Gorontalo 
ini. Pada studi ini dikaji status jalan yang tepat untuk Jalan Lingkar Luar Gorontalo berdasarkan 3 aspek kajian, yaitu berdasarkan aspek hierarki pusat kegiatan di Provinsi Gorontalo, aspek geometri jalan, dan aspek pemodelan lalu lintas.

Menurut statusnya, pengelompokan jalan umum disebutkan dalam Pasal 26, PP No. 34 Tahun 2006, tentang Jalan, seperti yang ditunjukkan oleh Tabel 2. Dalam membuat pengembangan jaringan transportasi, hal yang cukup penting untuk diperhatikan adalah tatanan struktur tata ruang wilayah nasional, yang di dalamnya memuat sistem kota atau permukiman dan pola jaringan transportasi.

Tabel 2 Pengelompokan Status Jalan Umum

\begin{tabular}{|c|c|c|}
\hline No. & Status Jalan & Keterangan \\
\hline 1 & Jalan Nasional & $\begin{array}{l}\text { a. Jalan arteri primer } \\
\text { b. Jalan kolektor primer yang menghubungkan antaribukota provinsi } \\
\text { c. Jalan tol } \\
\text { d. Jalan strategis nasional }\end{array}$ \\
\hline 2 & Jalan Provinsi & $\begin{array}{l}\text { a. Jalan kolektor primer yang menghubungkan ibukota } \\
\text { provinsi dengan ibukota kabupaten atau kota } \\
\text { b. Jalan kolektor primer yang menghubungkan antaribukota kabupaten atau kota } \\
\text { c. Jalan strategis nasional } \\
\text { d. Jalan di daerah khusus ibukota Jakarta, kecuali jalan No. } 1\end{array}$ \\
\hline 3 & Jalan Kabupaten & $\begin{array}{l}\text { a. Jalan kolektor primer yang tidak termasuk jalan nasional No. 1b dan jalan } \\
\text { provinsi No. } 2 \\
\text { b. Jalan lokal primer yang menghubungkan ibukota } \\
\text { kabupaten dengan ibukota kecamatan, ibukota kabupaten dengan pusat desa, } \\
\text { antaribukota kecamatan, ibukota kecamatan dengan desa, dan antardesa } \\
\text { c. Jalan sekunder yang tidak termasuk jalan provinsi sebagaimana dimaksud } \\
\text { dalam No. 2d dan jalan sekunder dalam kota } \\
\text { d. Jalan strategis kabupaten }\end{array}$ \\
\hline 4 & Jalan Kota & Jalan umum pada jaringan jalan sekunder di dalam kota \\
\hline 5 & Jalan Desa & $\begin{array}{l}\text { Jalan lingkungan primer dan jalan lokal primer yang tidak termasuk jalan } \\
\text { kabupaten No. 3b di dalam kawasan perdesaan, dan merupakan jalan umum } \\
\text { yang menghubungkan kawasan dan/atau antarpermukiman di dalam desa }\end{array}$ \\
\hline
\end{tabular}

Sumber: Pemerintah Republik Indonesia (2006).

Kota memiliki 2 pengertian, yaitu: (a) kota sebagai administratif yang ditetapkan dengan suatu keputusan pemerintah; dan (b) kota sebagai fungsional yang memiliki jumlah penduduk tertentu, fasilitas pelayanan jasa, adanya kegiatan ekonomi dan sosial, serta terdapatnya kepadatan penduduk yang relatif tinggi. Adisasmita (2011) menyebutkan bahwa pada perencanaan suatu wilayah, terdapat suatu hierarki dan organisasi pusat kegiatan, yaitu skala besar, skala sedang, dan skala kecil, yang tersusun dengan baik dan disebut dengan Sistem Pusat Kegiatan.

Menurut Peraturan Pemerintah No. 26 Tahun 2008, tentang Rencana Tata Ruang Wilayah Nasional (RTRWN), secara hierarkis kawasan perkotaan dibedakan atas:

1) Pusat Kegiatan Nasional (PKN), yang berfungsi untuk melayani kegiatan skala internasional, nasional, atau beberapa provinsi. PKN juga merupakan pusat pengumpul, pemasaran komoditas unggulan, dan sebagai simpul utama transportasi yang menghubungkan kawasan yang satu dengan kawasan yang lain; 
2) Pusat Kegiatan Wilayah (PKW), yang berfungsi untuk melayani kegiatan skala provinsi atau beberapa kabupaten/kota. PKW juga merupakan pusat pengolahan, pengumpul, pemasaran komoditi unggulan dan sebagai simpul transportasi wilayah, serta penghubung antara PKN dan Pusat Kegiatan Lokal (PKL); dan

3) Pusat Kegiatan Lokal (PKL), yang berfungsi untuk melayani kegiatan skala kabupaten/ kota atau beberapa kecamatan. PKL juga merupakan pusat pengumpul, pemasaran komoditi unggulan, dan sebagai simpul transportasi lokal yang bersifat melayani daerah setempat.

Selain sistem perkotaan nasional tersebut, dikembangkan Pusat Kegiatan Strategis Nasional (PKSN) untuk mendorong perkembangan kawasan perbatasan negara. PKSN tercantum dalam Peraturan Pemerintah No. 26 Tahun 2008, tentang Rencana Tata Ruang Wilayah Nasional (RTRWN). Jaringan jalan strategis nasional dikembangkan untuk menghubungkan: (1) antar-PKSN dalam satu kawasan perbatasan negara; (2) antara PKSN dan pusat kegiatan lainnya; dan (3) PKN dan/atau PKW dengan kawasan strategis nasional. Hubungan antara hierarki kota dengan fungsi jalan dalam sistem jaringan jalan primer di Indonesia dapat dilihat pada Tabel 3.

Tabel 3 Hubungan antara Hierarki Kota dengan Fungsi Jalan dalam Jaringan Jalan Primer di Indonesia

\begin{tabular}{cccccc}
\hline Hierarki Kota & PKN & PKW & PKL & PKLing & Persil \\
\hline PKN & Arteri & Arteri & Kolektor & Lokal & Lingkungan \\
PKW & Arteri & Kolektor & Kolektor & Lokal & Lingkungan \\
PKL & Kolektor & Kolektor & Lokal & Lokal & Lingkungan \\
PKLing & Lokal & Lokal & Lokal & Lokal & Lingkungan \\
Persil & Lingkungan & Lingkungan & Lingkungan & Lingkungan & Lingkungan \\
\hline
\end{tabular}

Sumber: Pemerintah Republik Indonesia, 2006.

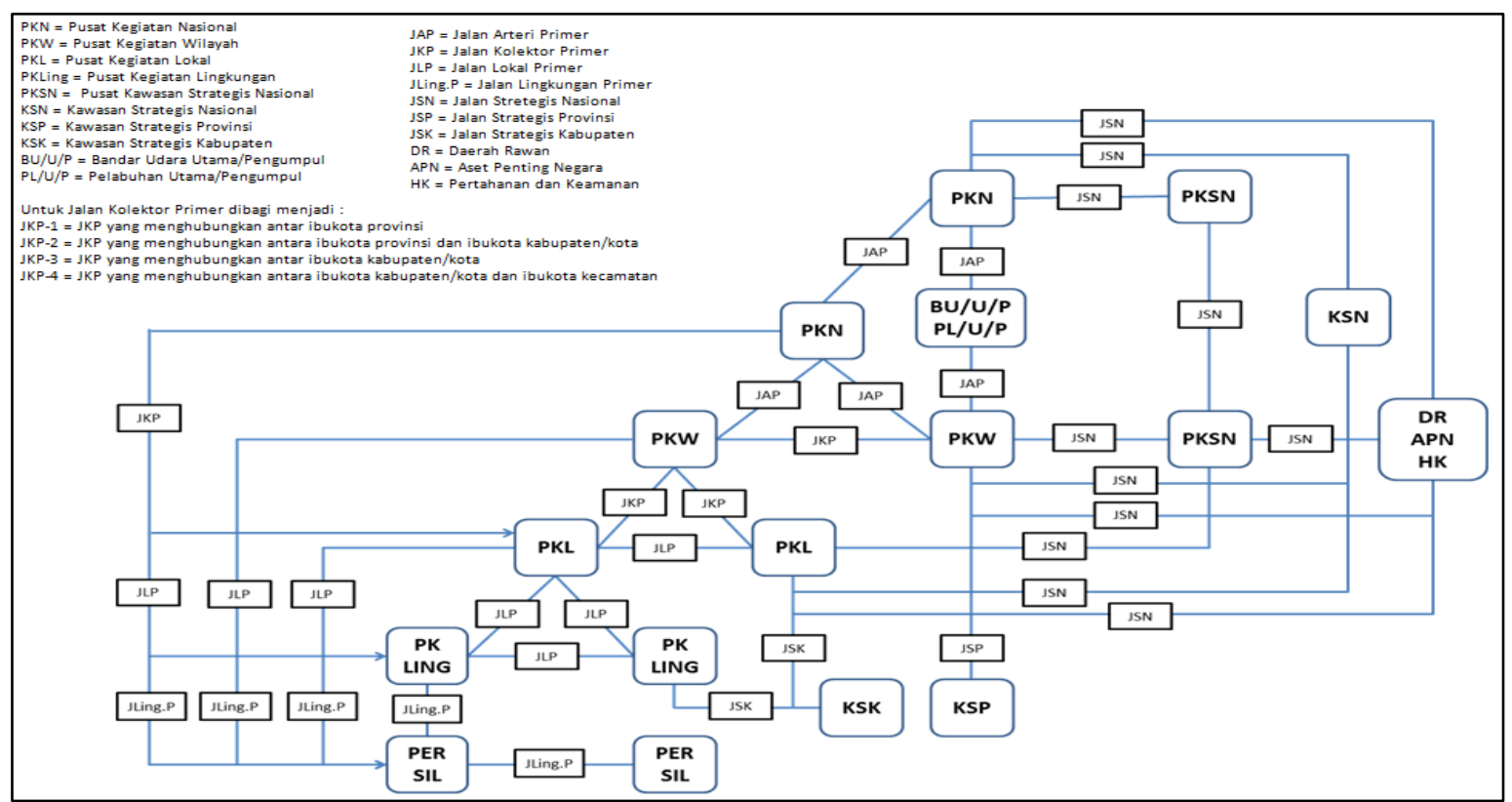

Gambar 3 Diagram Sistem Jaringan Jalan Primer di Indonesia 
Dalam diagram sistem jaringan jalan primer, jalan yang menghubungkan antara satu PKN dengan PKN lainnya adalah jalan arteri primer, sedangkan jalan yang menghubungkan PKN dengan PKW adalah jalan arteri primer. Jalan yang menghubungkan PKW dengan PKL adalah jalan kolektor primer dan jalan yang menghubungkan PKL dengan PKLing adalah jalan lokal primer. Diagram hierarki sistem jaringan jalan yang ada di Indonesia dapat dilihat pada Gambar 3.

Untuk dapat membahas status Jalan Lingkar Luar Gorontalo, diperlukan pemahaman mengenai pusat-pusat kegiatan yang ada di Provinsi Gorontalo. Menurut Peraturan Daerah Provinsi Gorontalo No. 4 Tahun 2011, tentang Rencana Tata Ruang Wilayah (RTRW) Provinsi Gorontalo Tahun 2010-2030, terdapat 3 hierarki sistem perkotaan di Provinsi Gorontalo, yaitu:

1) Pusat Kegiatan Nasional (PKN) : Kota Gorontalo

2) Pusat Kegiatan Wilayah (PKW): Isimu, Kwandang, Tilamuta, PKWp Marisa, dan PKWp Suwawa

3) Pusat Kegiatan Lokal (PKL) : Limboto, Suwawa, Paguyaman, Paguat, dan Popayato

Peta lokasi pusat-pusat kegiatan berjenis PKN dan PKW di Provinsi Gorontalo disajikan pada Gambar 4. Sesuai dengan pengelompokan status jalan umum, yang termasuk jalan nasional adalah jalan arteri primer, jalan kolektor primer, jalan tol, dan jalan strategis nasional. Setelah mengetahui pusat kegiatan nasional dan pusat-pusat kegiatan wilayah di Provinsi Gorontalo, dapat ditentukan fungsi dan sistem jaringan jalan di Provinsi Gorontalo. Berdasarkan informasi mengenai pusat-pusat kegiatan tersebut, selanjutnya dibuat diagram jaringan jalan nasional di Provinsi Gorontalo. Diagram jaringan jalan nasional di Provinsi Gorontalo berdasarkan lokasi PKN, PKW, dan PKWp dapat dilihat pada Gambar 5.

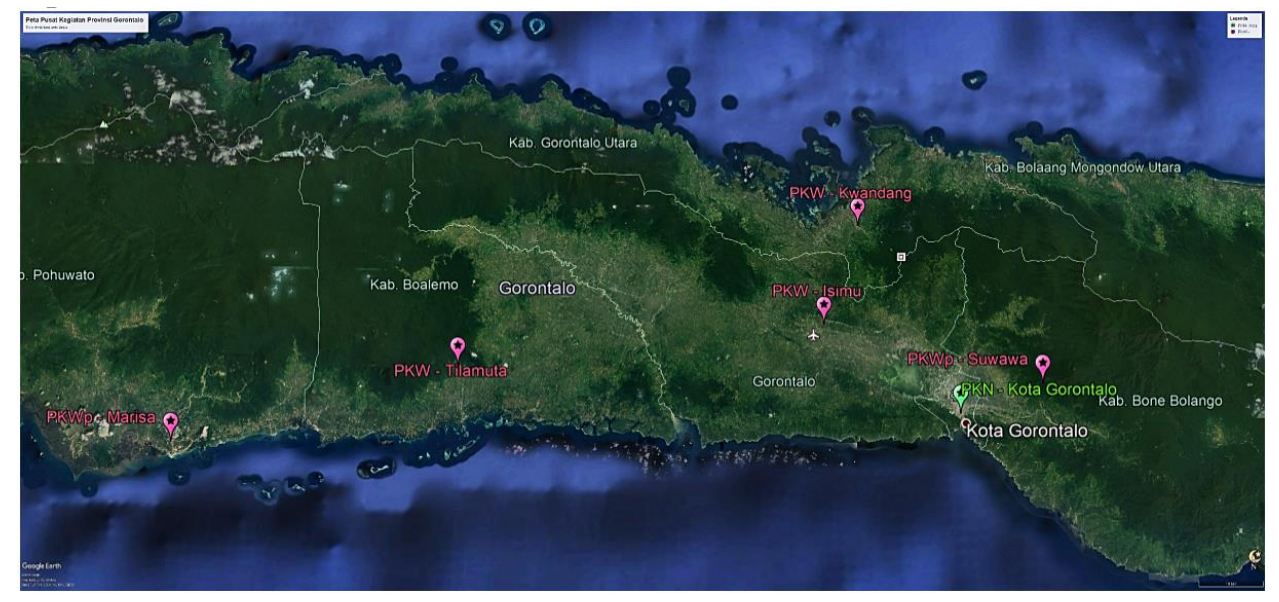

Gambar 4 Lokasi Pusat-Pusat Kegiatan di Gorontalo

Jalan Lingkar Luar Gorontalo terletak antara PKW Isimu dan PKN Kota Gorontalo. Dengan demikian, berdasarkan sistem jaringan jalan dan hierarki pusat kegiatan, Jalan Lingkar Luar Gorontalo bisa menjadi Jalan Arteri Primer dan statusnya dapat dijadikan Jalan Nasional. Saat ini, jalan nasional yang menghubungkan PKW Isimu dan PKN Kota Gorontalo adalah Jalan Trans Sulawesi. 


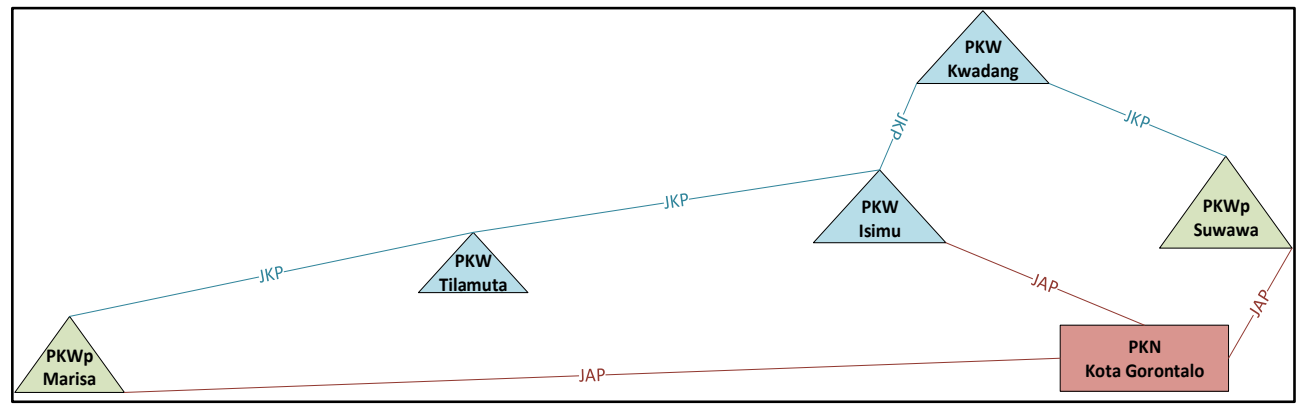

Gambar 5 Diagram Jaringan Jalan Nasional di Provinsi Gorontalo

\section{ASPEK GEOMETRI JALAN}

Dari aspek geometri jalan, Jalan Lingkar Luar Gorontalo memiliki 2 lajur 2 arah dengan lebar lajur sekitar 3,5 m. Jalan Trans Sulawesi juga merupakan jalan 2 lajur 2 arah dengan lebar lajur yang lebih kecil, yaitu sekitar 3,2 m. Secara desain geometri jalan, baik alinyemen horizontal maupun alinyemen vertikal, Jalan Lingkar Luar Gorontalo lebih unggul jika dibandingkan dengan Jalan Trans Sulawesi. Hal ini menyebabkan kecepatan rata-rata kendaraan yang melintas di Jalan Lingkar Luar Gorontalo bisa lebih tinggi dibandingkan dengan kecepatan rata-rata kendaraan yang melintas di Jalan Trans Sulawesi. Dengan demikian, Jalan Lingkar Luar Gorontalo memberikan mobilitas yang lebih tinggi jika dibandingkan dengan Jalan Trans Sulawesi.

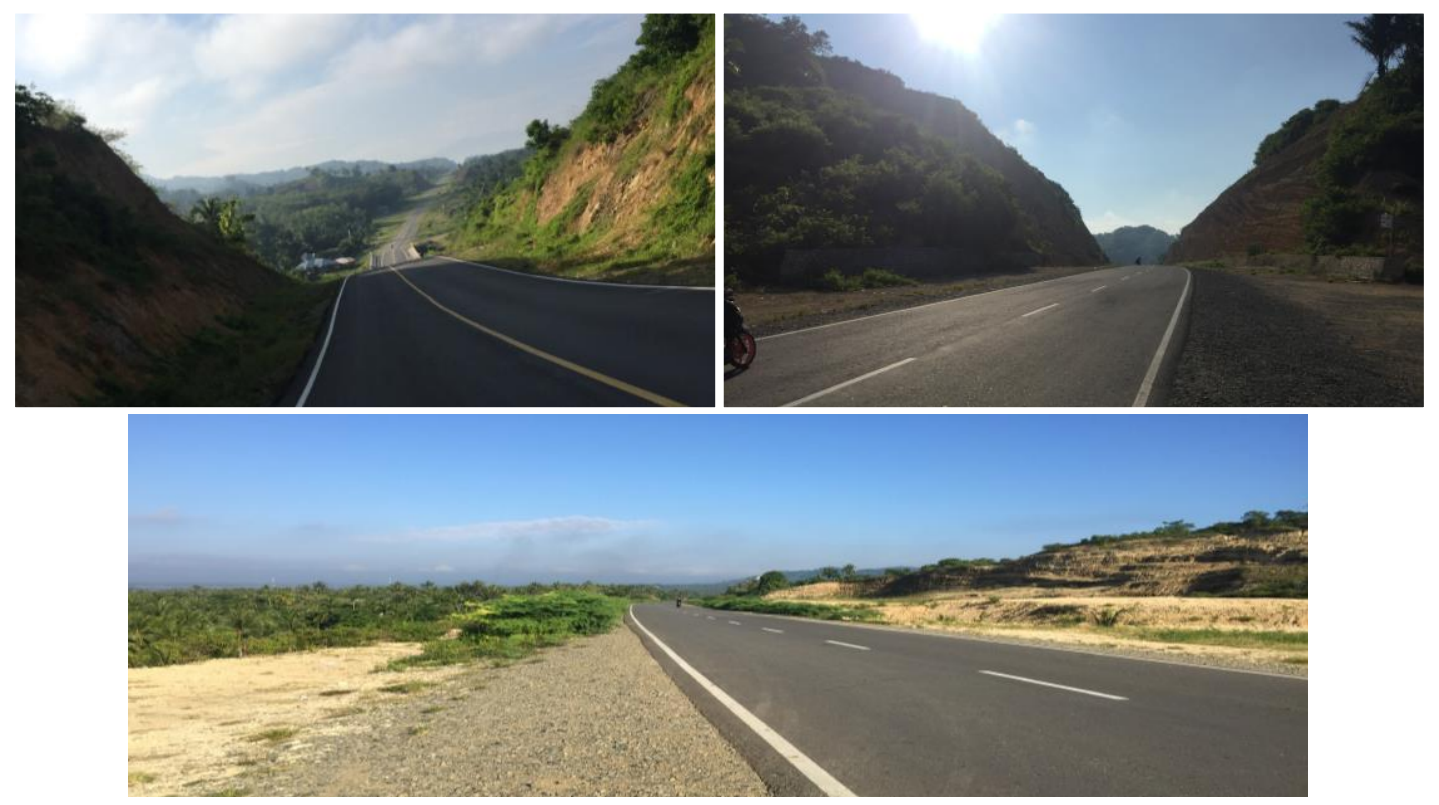

Gambar 6 Jalan Lingkar Luar Gorontalo

Dilihat dari tata guna lahan di sekitarnya, Jalan Trans Sulawesi merupakan jalan yang sudah padat permukiman di kanan dan di kirinya. Hal ini akan menyebabkan tingginya biaya pembebasan lahan jika di masa depan Jalan Trans Sulawesi direncanakan untuk dilebarkan 
atau ditambah jumlah lajurnya. Sebaliknya, Jalan Lingkar Luar Gorontalo terletak di area perkebunan dan area yang belum padat permukiman sehingga jalan tersebut akan lebih murah untuk dikembangkan atau ditambah kapasitasnya dengan pelebaran maupun penambahan lajur di masa depan. Pada penelitian ini juga telah dilakukan survei atau kunjungan lapangan untuk melihat langsung kondisi Jalan Lingkar Luar Gorontalo. Dokumentasi survei yang dilakukan ke Jalan Lingkar Luar Gorontalo dapat dilihat pada Gambar 6. Dengan melihat kenyataan yang ada, dapat dinyatakan bahwa Jalan Lingkar Luar Gorontalo lebih unggul jika dibandingkan dengan Jalan Trans Sulawesi berdasarkan lebar lajur, geometri jalan, kecepatan rata-rata kendaraan yang melintas, dan ketersediaan lahan untuk pengembangan.

\section{ASPEK LALU LINTAS}

Selain dari aspek hierarki pusat kegiatan dan aspek geometri jalan, studi ini juga mengkaji penetapan status Jalan Lingkar Luar Gorontalo dengan satu aspek lagi, yaitu aspek lalu lintas. Aspek lalu lintas diperlukan untuk melihat arus lalu lintas yang terjadi pada Jalan Lingkar Luar Gorontalo dan Jalan Trans Sulawesi. Ruas-ruas jalan yang dimasukkan ke dalam model adalah ruas-ruas yang merepresentasikan kapasitas jaringan jalan wilayah kajian yang sesungguhnya dan cukup detail agar tidak terjadi pembebanan yang berlebihan pada ruas jalan tertentu serta memberikan pengaruh atau dipengaruhi oleh keberadaan jalan rencana.

Berdasarkan tingkat analisis yang akan dilakukan, sistem jaringan jalan yang ditinjau untuk studi ini mengikutsertakan jaringan jalan arteri dan jalan kolektor primer, atau dari sisi status jalan, yaitu jalan nasional dan jalan provinsi di Sulawesi Utara dan di Gorontalo. Pemodelan yang dilakukan menggunakan beberapa asumsi, yaitu:

1. Pemodelan menggunakan Perangkat Lunak PTV Visum 15.

2. Zona yang digunakan adalah zona kota atau kabupaten.

3. Link yang digunakan adalah jaringan jalan nasional dan jalan provinsi yang terdapat pada SK Menteri PUPR No. 290 Tahun 2015, tentang SK Status Jalan.

4. Faktor pertumbuhan yang digunakan adalah $6 \%$ per tahun.

Data Bangkitan dan Tarikan Perjalanan menggunakan data dasar Asal Tujuan Transportasi Nasional (ATTN) 2011. Contoh rekapitulasi data ATTN 2011 yang telah dirangkum untuk melihat gambaran umum pola pergerakan di Provinsi Gorontalo dapat dilihat pada Tabel 4.

Dari hasil pemodelan seperti yang ditunjukkan pada Gambar 7, dapat dilihat bahwa Ruas Jalan Lingkar Luar Gorontalo memberikan dampak yang signifikan terhadap pergerakan through traffic. Dilihat dari kapasitas jalan dan kecepatan rata-rata kendaraan yang melintas, Jalan Lingkar Luar Gorontalo lebih unggul dibandingkan Jalan Trans Sulawesi. Dengan demikian, dapat disimpulkan bahwa Jalan Lingkar Luar Gorontalo memiliki mobilitas yang lebih tinggi dan arus lalu lintas yang diprediksi lebih besar dibandingkan dengan yang terdapat pada Jalan Trans Sulawesi. 
Tabel 4 Contoh Rekapitulasi Asal Tujuan Transportasi Nasional di Provinsi Gorontalo

\begin{tabular}{clllll}
\hline No. & Provinsi Asal & Kabupaten Aasal & Provinsi Tujuan & Kabupaten Tujuan & Nilai Asal Tujuan \\
\hline 244032 Gorontalo & Kota Gorontalo & Gorontalo & Gorontalo & 446.371 \\
120776 Gorontalo & Gorontalo & Gorontalo & Kota Gorontalo & 374.267 \\
244028 Gorontalo & Boalemo & Gorontalo & Gorontalo & 210.560 \\
244029 Gorontalo & Bone Bolango & Gorontalo & Gorontalo & 201.442 \\
120773 Gorontalo & Gorontalo & Gorontalo & Bone Bolango & 184.056 \\
120772 Gorontalo & Gorontalo & Gorontalo & Boalemo & 164.544 \\
244169 Gorontalo & Kota Gorontalo & Gorontalo & Bone Bolango & 154.056 \\
120913 Gorontalo & Bone Bolango & Gorontalo & Kota Gorontalo & 141.372 \\
244302 Gorontalo & Kota Gorontalo & Gorontalo & Gorontalo Utara & 125.129 \\
121046 Gorontalo & Gorontalo Utara & Gorontalo & Kota Gorontalo & 110.915 \\
120843 Gorontalo & Boalemo & Gorontalo & Pahuwato & 90.793 \\
244099 Gorontalo & Pahuwato & Gorontalo & Boalemo & 87.530 \\
120845 Gorontalo & Boalemo & Gorontalo & Kota Gorontalo & \\
244101 Gorontalo & Kota Gorontalo & Gorontalo & Boalemo & 70.798 \\
120844 Gorontalo & Boalemo & Gorontalo & Gorontalo Utara & \\
\hline
\end{tabular}

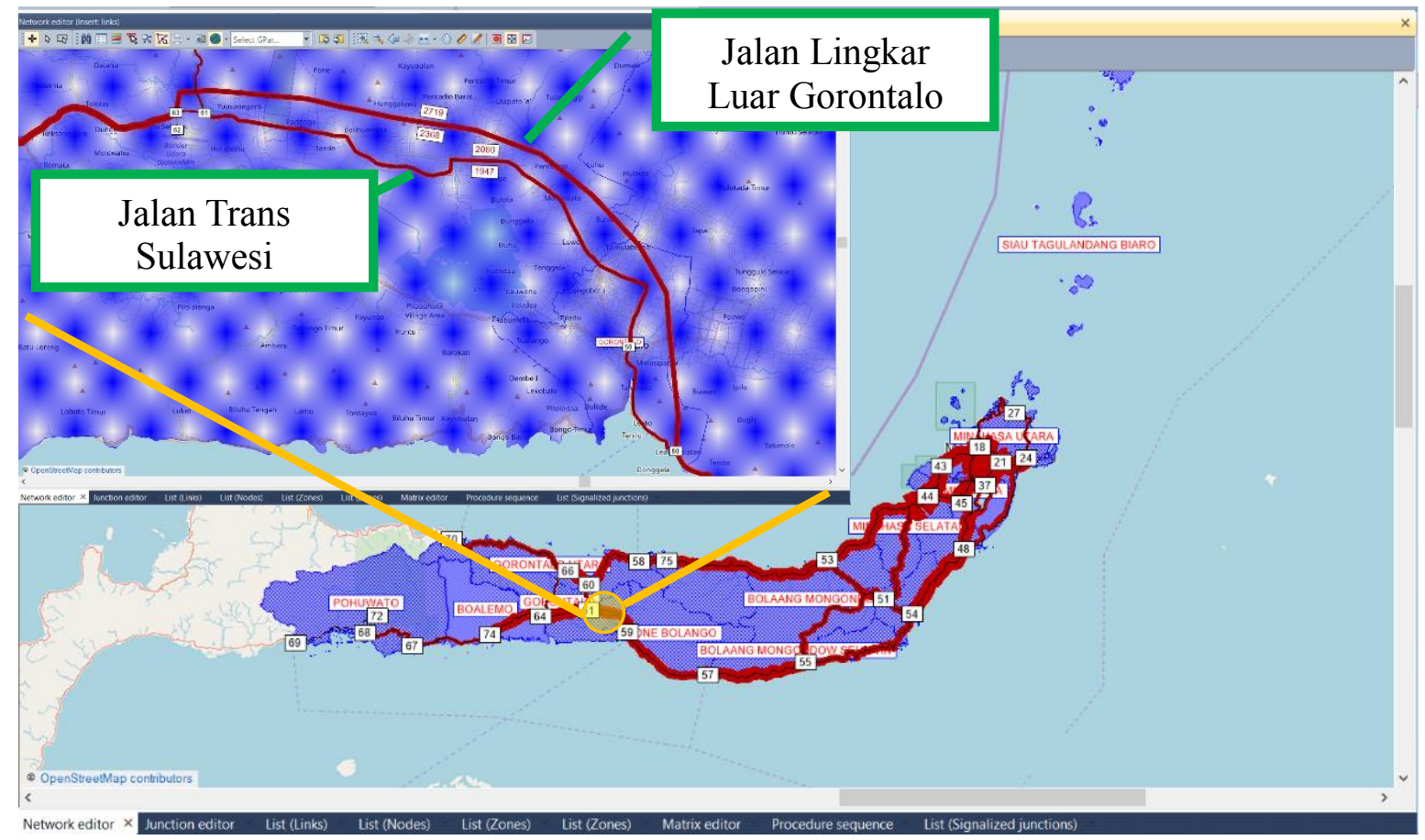

Gambar 7 Hasil Pemodelan Ruas Gorontalo Outer Ring Road

\section{KESIMPULAN}

Berdasarkan studi ini dapat disimpulkan bahwa setelah Jalan Lingkar Luar Gorontalo terhubung sepenuhnya, Jalan Lingkar Luar Gorontalo sebaiknya diberi status Jalan Nasional. Jalan Lingkar Luar Gorontalo ini diharapkan dapat mengalihkan pergerakan kendaraan yang masuk menuju ke dalam Kota Gorontalo ke ruas tersebut, sehingga volume kendaraan di dalam Kota Gorontalo dapat berkurang. 
Dampak dari diangkatnya ruas Jalan Lingkar Luar Gorontalo menjadi jalan nasional adalah bahwa ruas-ruas jalan nasional yang melayani pergerakan menuju ke Kota Gorontalo, yaitu Jalan Trans Sulawesi, direkomendasikan untuk diturunkan menjadi jalan provinsi, karena Jalan Lingkar Luar Gorontalo lebih unggul dibandingkan dengan Jalan Trans Sulawesi dilihat dari 3 aspek, yaitu aspek hierarki pusat kegiatan, aspek geometri jalan, dan aspek lalu lintas. Dengan demikian, Jalan Lingkar Luar Gorontalo, sebagai jalan nasional, dapat melayani PKN Gorontalo dengan lebih baik.

\section{DAFTAR PUSTAKA}

Adisasmita, S.A. 2011. Transportasi dan Pengembangan Wilayah. Yogyakarta: Graha Ilmu. Badan Penelitian dan Pengembangan Kementerian Perhubungan. 2011. Asal Tujuan Transportasi Nasional. Jakarta.

Fachrie, N. dan Rudiarto, I. 2016. Kajian Variabel Penentu Peningkatan Status Jalan Nasional di Lintas Selatan Jawa Barat. Jurnal Pembangunan Wilayah dan Kota, 12 (1): 73-86. Kementerian Pekerjaan Umum dan Perumahan Rakyat. 2015a. Keputusan Menteri Pekerjaan Umum dan Perumahan Rakyat No. 290/KPT/M/2015 tentang Penetapan Ruas Jalan Menurut Statusnya sebagai Jalan Nasional. Jakarta.

Kementerian Pekerjaan Umum dan Perumahan Rakyat. 2015b. Keputusan Menteri Pekerjaan Umum dan Perumahan Rakyat Nomor 248/KPTS/M/2015 tentang Penetapan Ruas Jalan dalam Jaringan Jalan Primer Menurut Fungsinya sebagai Jalan Arteri (JAP) dan Jalan Kolektor 1 (JKP-1). Jakarta.

Pemerintah Daerah Provinsi Gorontalo. 2011. Peraturan Daerah Provinsi Gorontalo Nomor 4 Tahun 2011 tentang Rencana Tata Ruang Wilayah Provinsi Gorontalo Tahun 20102030. Gorontalo.

Pemerintah Republik Indonesia. 2006. Peraturan Pemerintah Republik Indonesia Nomor 34 Tahun 2006 tentang Jalan. Jakarta.

Pemerintah Republik Indonesia. 2008. Peraturan Pemerintah Republik Indonesia Nomor 26 Tahun 2008 tentang Rencana Tata Ruang Wilayah Nasional. Jakarta.

Purnomo, R.A.P. dan Rahardjo, B. 2014. Kajian Perubahan Status Jalan Provinsi menjadi Nasional pada Ruas Jalan Ketapang-Batas Kabupaten Pamekasan, Madura (No. Link 224). Jurnal Teknik POMITS, 1 (1): 1-6. 